of andesitic composition ${ }^{7}$. Instead, the dense crystalline residue, formed by the fractionation of the basalt and crustal melting, must separate from the crust by a process called delamination and sink into the mantle. This process could explain the evolution of the Sierra Nevada ${ }^{8}$. The great silicic intrusions - themselves clearly mixed ${ }^{9}$ and once vented through an andesitic mountain range - lost a mafic substrate through delamination. With its anchor gone and replaced by a hot mantle, the Sierra rose and a new outburst of volcanism began that persists today along the Sierran front. This is crustal differentiation as much as magma differentiation, and it need not be limited to subduction zones.

There is no compelling reason to believe that the continents are still growing, either. Rates of continent-derived sediment subduction are comparable to rates of magma generation at subduction zones $^{10}$. There may be no net gain in continental mass. All this casts doubt on the pleasant uniformitarian picture of subduction today, integrated over eons, slowly building the continents. Instead, there is mounting evidence that much continental crust formed early in Earth's history. Some favour catastrophic pulses of crustal generation emanating from the mantle ${ }^{11}$. Another way to drive crustal differentiation is through asteroid impact. The $>10,000 \mathrm{~km}^{3}$ Sudbury Igneous Complex in Canada, was recently found to be an impact melt sheet so thick it differentiated to produce voluminous granitic rocks ${ }^{12}$. Heavy bombardment of Earth could have contributed to early formation of continental crust. Uniformitarianism, which overcame old catastrophist thinking more than a century ago, is now being tempered by a new catastrophism.

Kent et al. ${ }^{2}$ advocate the mixing of basaltic and silicic magmas as the mechanism by which andesites form at Mount Hood. To explain the absence of either component of the mixtures as surface lavas, they propose recharge filtering. If the primary magma introduced into the crust is basaltic, then subduction alone cannot help continents grow. Subduction is then merely an assembler of continents and other crustal fragments. In fact, through subduction of sediments eroded from the top of continents and grinding away of the underside of continental plates by subduction, continents may literally be losing ground.

John Eichelberger is at the United States Geological Survey, USGS Headquarters, Reston, Virginia 20192-0002, USA.

e-mail: jeichelberger@usgs.gov



4. Pallister, J. S., Hoblitt, R. P. \& Reyes, A. G. Nature 365, 426-428 (1992).

5. Murphy, M. D. et al. Geophys. Res. Lett. 25, 3433-3436 (1998).

6. Eichelberger, J. C. \& Izbekov, P. E. Phil. Trans. R. Soc. A 358, 1465-1485 (2000)

7. Rudnick, R. L. Nature 378, 571-578 (1995).

8. Manley, C. R., Glazner, A. F. \& Farmer, G. L. Geology 28, 811-814 (2000).

9. Reid, J. B. Jr, Evans, O. C. \& Fates, D. G. Earth Planet. Sci. Lett. 66, 243-261 (1983).

10. von Huene, R. \& Scholl, D. W. Rev. Geophys. 29, 279-316 (1991).

11. Pearson, D. G., Parman, S. W. \& Nowell, G. M. Nature 449, 202-205 (2007).

12. Grieve, R. A. F., Cintala, M. J. \& Therriault, A. M. Geol. S. Am. S. 405, 23-31 (2006).

\title{
CORE PROCESSES
}

\section{Core curiosity}

Sir Isaac Newton was one of the first scientists to calculate that the average density of the Earth must be twice that of the surface rocks and therefore proposed the existence of a dense interior. We now know that the Earth's core is composed principally of iron and consists of a solid, crystalline inner core inside a liquid outer core. The inner core started to develop as the Earth began cooling after its initial formation, and it continues to grow: under the prevalent extreme conditions of both temperature and pressure, the dense iron crystallizes into solid form out of a mush of other elements.

The inner core exhibits some puzzling qualities. Separated from the rest of Earth by the fluid outer core, it can wobble and rotate. Seismic waves that are generated by earthquakes and propagate through the inner core travel much faster when going from south to north than when travelling in a direction parallel to the Equator. The inner core also exhibits an east-west asymmetry, with seismic waves travelling slightly faster in the

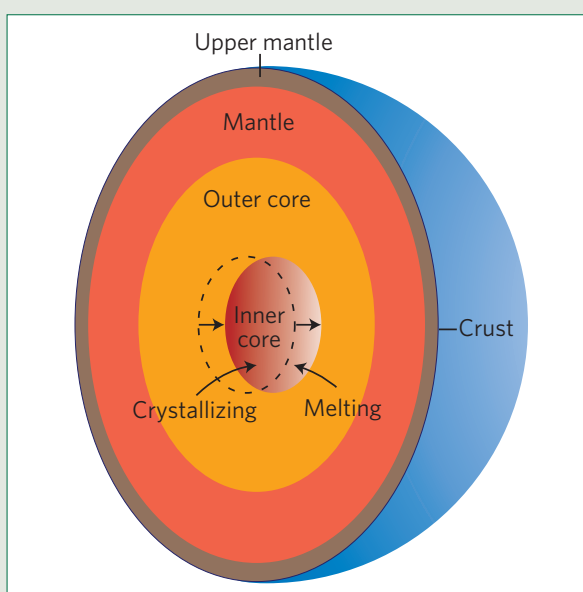

upper surface of the eastern hemisphere compared with that of the western hemisphere. Furthermore, seismic waves are observed to travel slowly through a thick layer that surrounds the inner core. This layer is thought to be a dense fluid.

Thierry Alboussière at the Joseph Fourier University, Grenoble, and colleagues present a theory to explain these curiosities (Nature 466, 744-747; 2010). They propose that instead of sitting at the precise centre of the Earth, the inner core could be offset to the east: if the density of the solid inner core was higher, say, in the west, the entire mass would be pushed slightly eastwards by the forces of gravity. If so, the western side of the inner core experiences greater pressure compared with the east and hence the iron crystallizes faster. Similarly, on the eastern side the iron melts.

The proposed process is selfreinforcing: as the inner core grows in size, the newly solidifying iron in the west crystallizes at increasingly low pressures and is thus cooler and denser than the liquid melt in the east, so the inner core is kept in its offset position. Over time, iron solidified at the western boundary migrates eastwards. And most of it - all that does not contribute to the net growth of the inner core - finally melts back into the outer core.

\section{AMY WHITCHURCH}

